\title{
Informatization Transformation of College English Teaching from the Perspective of Pragmatic Competence
}

\author{
Xiaoyi LIU \\ Foreign Language Department of Jilin Business and Technology College \\ Changchun City, China, \\ Email:lihongbin1975@163.com
}

\begin{abstract}
The deep integration of information technology and college English can greatly develop the comprehensive quality of college students and improve teaching efficiency and quality so as to promote the leap-forward development of college English teaching. With the information technology development today, the smooth realization of informationbased transformation of college English teaching from pragmatic competence perspective is not only a necessary measure of the reform of college English teaching, but also more close to the English teaching requirements at the same time, which is regarded as an important way to promote the development of students comprehensive abilities. Combining with the specific requirements of the college English teaching from pragmatic competence perspective, this paper revolves around the main problems of the present college English and especially puts forward concrete suggestions and comments for the informatization transformation of college English teaching.
\end{abstract}

Keywords-college english; informationization teaching; pragmatic competence

With the application and promotion of information technology in the worldwide, college English teaching also begins to face new challenges. Pragmatic competence is an important indicator to measure students' integrated English level. The development of information technology makes the pragmatic competence of college English teaching has more new directions, as a matter of course, informatization transformation of college English teaching from the perspective of pragmatic competence has surely become the top issue the present college English teaching is face with.

\section{OBJECTIVE REQUIREMENT OF PRAGMATIC COMPETENCE FOR YHE ENGLISH TEACHING IN COLLEGES AND UNIVERSITIES}

Pragmatic competence, on the literal meaning, is the language users' ability to communicate successfully with correct use of English sentences. English teaching in colleges and universities objectively requires students to have a certain basic knowledge of language and pay attention to the appropriateness of language use. Only when the two aspects are properly dealt with can students complete a successful communication. With the English language skills' deepening and popularization in social application in various fields, the college English teaching's cultivation of students' pragmatic competence is increasingly prominent.

College English teaching, in order to cultivate students' pragmatic competence, firstly needs to attach enough importance to basic knowledge. Students' flexible application of language is cultivated and motivated by constant accumulation of knowledge. Only when their knowledge reaches a certain degree can they use it successfully.

To improve students' English pragmatic competence seems to be more inclined to apply the teaching goal, but essentially, it is not hard to find that the higher requirements for students' pragmatic competence are based on the firm mastery of basic knowledge. Therefore, for the contemporary college English teaching, the consolidation of basic knowledge, especially grammar, is still the top priority. Of course, in addition to the basic knowledge, it is also essential to pay attention to methods and practice. Therefore, in college English teaching, pragmatic competence perspective appears to be a new way of teaching, but essentially for English curriculum itself, puts forward a huge challenge. $^{[1]}$

\section{NECESSITY OF INFORMATIONIZATION TRANSFORMATION OF COLLEGE ENGLISH TEACHING FROM PRAGMATIC COMPETENCE PERSPECTIVE}

The development of times and the expansion of application scope of English skills make college English teaching attach importance to the students' pragmatic competence cultivation. But in such a new environment and condition, college English teaching always has the following problems, which seriously influences the implementation of teaching reform.

\section{A. Excessive passiveness of students}

Different from the passiveness in the traditional teaching, students' lack of enthusiasm in the process of college English teaching is not because of their deficiency in 
intelligence, but due to lack of motivation. Students are active and thoughtful, but there is a lack of motivation in their minds, as a direct result, learning efficiency becomes low. For this situation, if teachers can adopt diversified measures to rich class content and improve class activeness, students will inevitably reverse their inherent definition to English teaching and discover the charm of English classroom, as a matter of course, students' autonomous learning interest is stimulated and their enthusiasm of pragmatic competence is improved, which eventually forms a virtuous teaching cycle.

\section{B. Difficulty in understanding teachers' teaching intention}

Under the perspective of pragmatic competence, college English courses have a higher and higher requirement for increasing the flexibility and application of teaching, but have to face the pressure of exam-oriented education mode. In such a "dilemma", education workers have been striving to form a kind of benign interaction between teachers and students. But in the process of groping, it is not hard to find that to cultivate students' "pragmatic competence" means to promote positive interaction between teachers and students, grab the students' psychological expectations and meet students' desire, but the teachers always focus on the boring teaching content and don't understand how to explore a more flexible way dealing with the relationship between teachers and students. ${ }^{[2]}$ The application of information technology in college English teaching is able to create a a comprehensive audiovisual environment for students from the learning methods so as to improve students' basic knowledge, strengthen student's language sense and enhance the students' pragmatic competence comprehensively.

\section{EFFECTIVE APPROACH OF INFORMATIONIZATION TRANSFORMATION OF COLLEGE ENGLISH TEACHING FROM PRAGMATIC COMPETENCE PERSPECTIVE}

The informationization transformation of college English teaching and college English pragmatic competence perspective is a set of relationships complementary to each other. Pragmatic competence perspective objectively requires to update teaching mode-the all-direction application of the newly emerged information technology. As for the application of information technology, it cannot work without the dynamic pragmatic competence as a starting point. Therefore, in terms of the combination of the two, it is the inevitable result of the college English teaching reform, at the same time, it is also a necessary approach to promote the development of students comprehensive quality from the college English teaching practice. In the following, the author combines with personal teaching experience and focuses on implementation method and strategy for informationization transformation of college English teaching from pragmatic competence perspective.

\section{A. Innovation of teaching mode}

The most important thing for the informationization transformation of college English teaching from pragmatic competence perspective is to innovate the teaching mode of college English. In traditional college English teaching mode, teachers are generally playing dominant roles and students at most only act as the role of listeners. In this process, the teachers control the whole process of teaching without students' involvement in class activities. In terms of the integration of information technology and college English teaching, teachers can try some new ways to explain the teaching content. In such a teaching process, students almost have no chance to practice the basic exercises, let alone the pragmatic ability.

Actually, combined with the present college English curriculum content, most of the content can be found through the internet related topics, articles, and videos and so on. In the teaching process, teachers can firstly try to let students watch some related videos in advance in order to attract the attention of the students and stimulate students' interest. At the same time of strengthening students' basic grammar knowledge, students' language sense and pragmatic ability can be ascended by means of innovative teaching modes. If conditions permit, teachers also can arrange viewing course or topic discussion to presents the corresponding teaching contents for students through the three-dimensional multimedia platform. The course discussion or debate actually is an opportunity and platform for students' sublimation thinking. In this way, it can not only improve students' the pragmatic competence, but also can play the corresponding driving and promoting role for the reform of college English teaching at the same time.

\section{B. Establishment of various communication platforms}

In addition to the innovation and breakthrough of teaching mode, teachers can also start from the perspective of the communication platform, using social platforms such as micro-blog, wechat and QQ, set up "online English corner" so as to create a three-dimensional learning environment for students and to create the opportunity as far as possible for students to communicate in English. Teachers should make a statistic analysis in advance and plan to set up a real-time communication platform.

Using a form of social sharing lets the student imagine their future life in details, helps students build up the link between learning and real life, improve the student's interest in learning in the curriculum content, and turn the English expressions into a habitual form of expression.

In addition, in the traditional mode, the communication between teachers and students is relatively stiff, and the relationship between teachers and students is weak, as a consequence, teachers are unable to understand their students' thoughts, and students do not understand their teacher's position. In such a poor state, it is actually difficult to improve the teaching quality and create a good teaching atmosphere. If teachers can from these new social platforms, they will find it easy to know about student's psychological state, which is bound to play a significant role in the informationization transformation of college English teaching from pragmatic competence perspective. 


\section{Improvement of students' information skills}

If colleges and universities set up many kinds of communication platforms, learners can completely improve their pragmatic competence in the virtual world. With the development of science and technology, human communication has broken the limits of time and space. The sharing advantages of network multimedia resources can make the English learners access to learning content anytime and anywhere. Learners can search information related to study on the Internet and browse all kinds of words, pictures and other information related to the English resources. At the same time, they also can download or search online answers, watch English audios and videos, etc. The promptness and richness of network resources make learners' interest in learning English and the effect of English acquisition be greatly improved. In this context, we should encourage students to make full use of modern science and technology to broaden channels of communication. For example, we can require students to use English chat rooms to practice oral English as well as to improve pragmatic competence. ${ }^{[3]}$

English informationization teaching mainly focuses on the application of information and communication technology in English learning and teaching. It takes advantage of network, text, picture, audio and video and turns the abstract concept of linguistics to understandable content, so that the students can easily learn English in an open, diverse and free campus environment. It gives students more learning initiative and enthusiasm to study English and offers the flexibility of operation mode, which can make students improve their English level, comprehensive application ability and information retrieval, information analysis, information processing ability in real or simulated environment. This three-dimensional way of teaching mode conforms to the theory of language learning and language teaching, and also conforms to the modern education thought, which is an important development direction of modern foreign language education and is to show people the new prospects of foreign language teaching.

\section{CONCLUSION}

From what has been discussed above, we can see, the pragmatic competence is an important indicator to measure students' integrated English level. The development of information technology makes the pragmatic competence of college English teaching have more new directions, and informatization transformation of college English teaching from the perspective of pragmatic competence also surely becomes the top issue that the present college English teaching is face with.

Combined with the current existing problems in college English teaching, students' passiveness and students' misunderstanding of teaching intention, the realization of informatization transformation of college English teaching from the perspective of pragmatic competence should firstly make teaching innovation to stimulate students' interest. In addition, establishment of a variety of communication platforms, including wechat, micro-blog and other social media platforms such as QQ can set up an "online English corner" and create a three-dimensional learning environment for students. At last, teachers still should cultivate the students' information skills to enhance their pragmatic competence.

\section{REFERENCE}

[1] Department of Higher Education. College English Curriculum Requirements[ M]Shanghai: Shanghai Foreign Language Education Press, 2004

[2] Liu Changjiang.The imbalance and reconstruction of college English classroom ecology in context of informationization[D]. Shanghai International Studies University,2013

[3] Nunan, D. Second Language Teaching and Learning [M].Beijing:Foreign Language Teaching and Research Press, 2001:25 